UDC 633.33:631.847.211

\author{
D.V. Krutylo ${ }^{1}$, N.O. Leonova ${ }^{2}$ \\ ${ }^{I}$ Institute of Agricultural Microbiology and Agro-industrial Manufacture, National Academy \\ of Agrarian Sciences, \\ 97 Shevchenko St., Chernihiv, 14027, Ukraine \\ ${ }^{2}$ Zabolotny Institute of Microbiology and Virology, National Academy of Sciences of Ukraine, \\ 154 Zabolotny St., Kyiv, 03143, Ukraine
}

\title{
SYMBIOTIC POTENTIAL OF BRADYRHIZOBIUM JAPONICUM STRAINS WITH DIFFERENT GROWTH RATES
}

\begin{abstract}
Aim. To study genetic properties of soybean nodule bacteria with different growth rates, to research the ability of rhizobia to produce phytohormonal substances and estimate their symbiotic potential in the conditions of combined inoculation and mono-inoculation of soybean plants. Methods. Sequencing of the 16S-23S rDNA intergenic spacer of soybean rhizobia was performed on ABI 3130xl Genetic Analyzer. Determination of the qualitative and quantitative composition of phytohormones in culture liquid of Bradyrhizobium japonicum strains was performed by SDTLC-chromatography of high resolution. Symbiotic potential of the strains was estimated in the field experiment in Polissia area of Ukraine. Results. It has been established that strains of soybean nodule bacteria with different growth rates by the structure of ITS region belong to different genetic groups: USDA 6, USDA 110 and USDA 123. The studied rhizobia differ in the levels of extracellular phytohormones synthesis: the slow-growing B. japonicum strain 46 produces more amounts of auxins, but the intensive-growing B. japonicum strain KB11 significantly exceeds in the amounts of cytokinins. It has been shown that an important factor of increasing soybean productivity is the formation of balanced symbiotic systems of the host plant with several complementary strains but serologically and genetically different strains of rhizobia of the same species. Conclusions. Combined inoculation of soybean seeds with two active strains B. japonicum 46 and B. japonicum KB11 allows more fully realizing the potential of symbiotic partners and receiving the higher yield.
\end{abstract}

K e y w o rd s: Bradyrhizobium japonicum, soybean, 16S-23S rDNA (ITS-region), auxins, cytokinins, competitiveness.

Recently, more attention is paid to research of nodule bacteria soil populations and their interaction with the strains-inoculums and a host plant [1]. These researches are necessary to understand the mechanisms responsible for the formation of genetic diversity of rhizobia in natural ecosystems and agrocenoses.

According to the literature typical microsymbionts of cultural soybeans in soils of Ukraine are the slow-growing bacteria of Bradyrhizobium japonicum species [2]. When monitoring soybean rhizobia populations across the country, for the first time among microsymbionts of this culture we have isolated the strains characterized by higher growth rate and conventionally called "strains with intensive growth rate". These strains have a complex of characteristic features and significantly differ from typical slow-growing soybean nodule bacteria in morphological, cultural, physiological, chemotaxonomic and serological properties $[3,4]$. It has been established that strains with intensive 
growth rate are characterized by better survival in the soil compared to slowgrowing nodule bacteria $[5,6]$.

Research of symbiotic features of isolates from soil soybean rhizobia populations allowed selecting the most active strains with different growth rates. Given that in soils of Ukraine along with typical slow-growing nodule bacteria there are rhizobia with intensive growth rate, it is important to research their relationships with each other and with a host plant.

According to many researchers, symbiosis of micro- and macroorganisms is significantly affected by phytohormonal substances, in particular auxins and cytokinins. Evaluation of producing growth-stimulating substances by nodule bacteria can be used for screening of the effective strains and analysis of their interaction with a plant [7-9].

The aim of the work was to study the genetic properties of soybean nodule bacteria with different growth rates, to research the ability of rhizobia to produce phytohormonal substances and to estimate their symbiotic potential in the conditions of combined inoculation and mono-inoculation of soybean plants.

Materials and methods. The objects of research were strains of soybean nodule bacteria with slow (B. japonicum 46, KC23, KH10) and intensive (B. japonicum $\mathrm{KB} 11, \mathrm{C} 1 \mathrm{~KB}, \mathrm{KC} 19, \mathrm{KC} 22, \mathrm{KC} 91, \mathrm{CK} 7)$ growth rates, active strain (B. japonicum M8), standard (B. japonicum 634b) and typical (B. japonicum USDA $6^{\mathrm{T}}=$ VKM B-1967) strains.

Cultivation of bacteria was carried out in flasks $(750 \mathrm{ml})$ on a rotary shaker (220 rev/min) at $26-28{ }^{\circ} \mathrm{C}$ on liquid mannitol-yeast nutrient medium with such composition $(\mathrm{g} / 1)$ : mannitol - 10.0; yeast extract -2.0 ; calcium gluconate -1.5 ; $\mathrm{K}_{2} \mathrm{HPO}_{4}-0.5 ; \mathrm{MgSO}_{4}-7 \mathrm{H}_{2} \mathrm{O}-0.2 ; \mathrm{NaCl}-0.1 ; \mathrm{FeCl}_{3} \cdot 6 \mathrm{H}_{2} \mathrm{O}-0.01 ; \mathrm{pH} 7.2$. Cultures of $B$. japonicum in the exponential growth phase (92-96 h) grown in the same medium were used as the inoculum. The amount of inoculum was $5 \%$ volume of the medium.

To separate the biomass the culture liquid of bacteria was centrifuged for $20 \mathrm{~min}$ at $9000 \mathrm{rev} / \mathrm{min}$ and at $+4{ }^{\circ} \mathrm{C}$. Cells of bacteria were washed with saline thrice in order to clean them from exopolymer residues, each time they were centrifuged under the same conditions. The supernatants were used for further research to extract phytohormonal compounds. The residue of cells was suspended in distilled water, then dried at $103-105{ }^{\circ} \mathrm{C}$ in a desiccator until constant weight. The amount of absolutely dry biomass (ADB) of microorganisms was determined gravimetrically.

Determination of qualitative and quantitative composition of phytohormones in culture liquids of strains B. japonicum 46 and B. japonicum KB11 was performed by the SDTLC-chromatography of high resolution $[10,11]$. Extracellular phytohormones were isolated from supernatants of nodule bacteria by the method described in [12]. Quantitative determination of auxins, cytokinins and abscisic acid was carried out by using a scanning spectrodensitometer ("Sorbfil", Russia Federation). Amount of extracellular phytohormones was calculated in mcg per $1 \mathrm{~g}$ of absolutely dry biomass (ADB) of producent. The standards were synthetic phytohormones SigmaAldrich (Germany) and Acros Organic (Belgium): auxins - indole-3-acetic acid, indole-3-butyric acid, indole-3-carboxylic acid, indole-3-carbinol, 
indole-3-acetic hydrazide, indole-3-carboxaldehyde; cytokinins - zeatin, transzeatin-riboside, kinetin, 6- $\left(\gamma, \gamma\right.$-Dimethylallylamino)purine ( $\mathrm{N}^{6}$-(2-Isopentenyl) adenine), isopentenyl adenosine and abscisic acid.

The ability of strains $B$. japonicum 46 and B. japonicum KB11 to produce growth stimulating substances was investigated in a bioassay with common bean cuttings (cultivar 'Lopata') using dilutions of culture liquids in a 1:10, $1: 50,1: 100,1: 200$ and 1:500 ratio with water by the standard method. The controls were the tap water and the preparation-standard - indole-3-acetic acid (IAA) in concentrations of $10^{-5} \mathrm{M}$.

When studying genetic properties of soybean rhizobia strains, DNA were isolated from 7 day cultures using a set "DNA-sorb B". For amplification of 16S-23S rDNA intergenic spacer (ITS-region) the primers were used: FGPS1490-72 5'-TGCGGCTGGATCCCCTCCTT-3' and FGPL132-38 5'-CCGGGTTTCCCCATT-3' $[13,14]$. Sequencing was performed on ABI 3130xl Genetic Analyzer. Comparative analysis of sequences obtained and sequences from GenBank database was performed using software BLASTN (version 2.2.22). The phylogenetic tree was constructed with program MEGA 3.1 using the algorithm Neighbor-Joining NJ.

The field research was carried out in conditions of Polissia of Ukraine (Institute of Agricultural Microbiology and Agro-industrial Manufacture NAAS, Chernihiv city) on the leached black soil. Inoculation load in all variants was 200-300 thousand cells per 1 seed. When applying combined inoculation of soybean with rhizobia strains with different growth rates, they were used in a ratio of 1:1. Previously, it had been established that this combination of strains was more effective than mono-inoculation. The seeds of soybean cultivar 'Ustia' were used. The repetition of the experiment was quadruple. The area of a record plot was $6 \mathrm{~m}^{2}$. Placing of record plots was randomized.

Polyclonal O-antisera to soybean rhizobia strains with different growth rates (B. japonicum KB11, 46, M8 and 634b) were obtained as it was described in [15]. Competitiveness of strains was determined using the reaction of agglutination [15].

Activity of symbiotic nitrogen fixation was measured by acetylene method using a gas chromatograph "Chrom-4” (Czech Republic).

Statistical processing of data was performed by standard methods and the software Statistica 7.0 was used.

Results and discussion. Genetic properties of soybean nodule bacteria. We have determined the phylogenetic affinity of soybean nodule bacteria strains with different growth rates, isolated from soils of Chernihiv, Kyiv, Sumy and Vinnitsa regions. As the molecular marker a taxonomically important area of DNA was used, such as intergenic spacer 16S-23S rDNA (ITS-region).

Comparative analysis of nucleotide sequences of ITS-region of slowgrowing strains $B$. japonicum $46, \mathrm{KC} 23$, KH10 and $634 \mathrm{~b}$ has shown that they belong to two different genetic groups (Fig. 1). Accordingly to the phylogram, strains B. japonicum 46, KC23 and $\mathrm{KH} 10$ formed one cluster (group of USDA 6), whereas the standard B. japonicum strain 634b was included in another cluster (group of USDA 110).

All the intensive-growing strains (B. japonicum KB11, KC19, KC22, KC91, $\mathrm{CK} 7, \mathrm{C} 1 \mathrm{~KB})$ - representatives of different populations - formed one group 


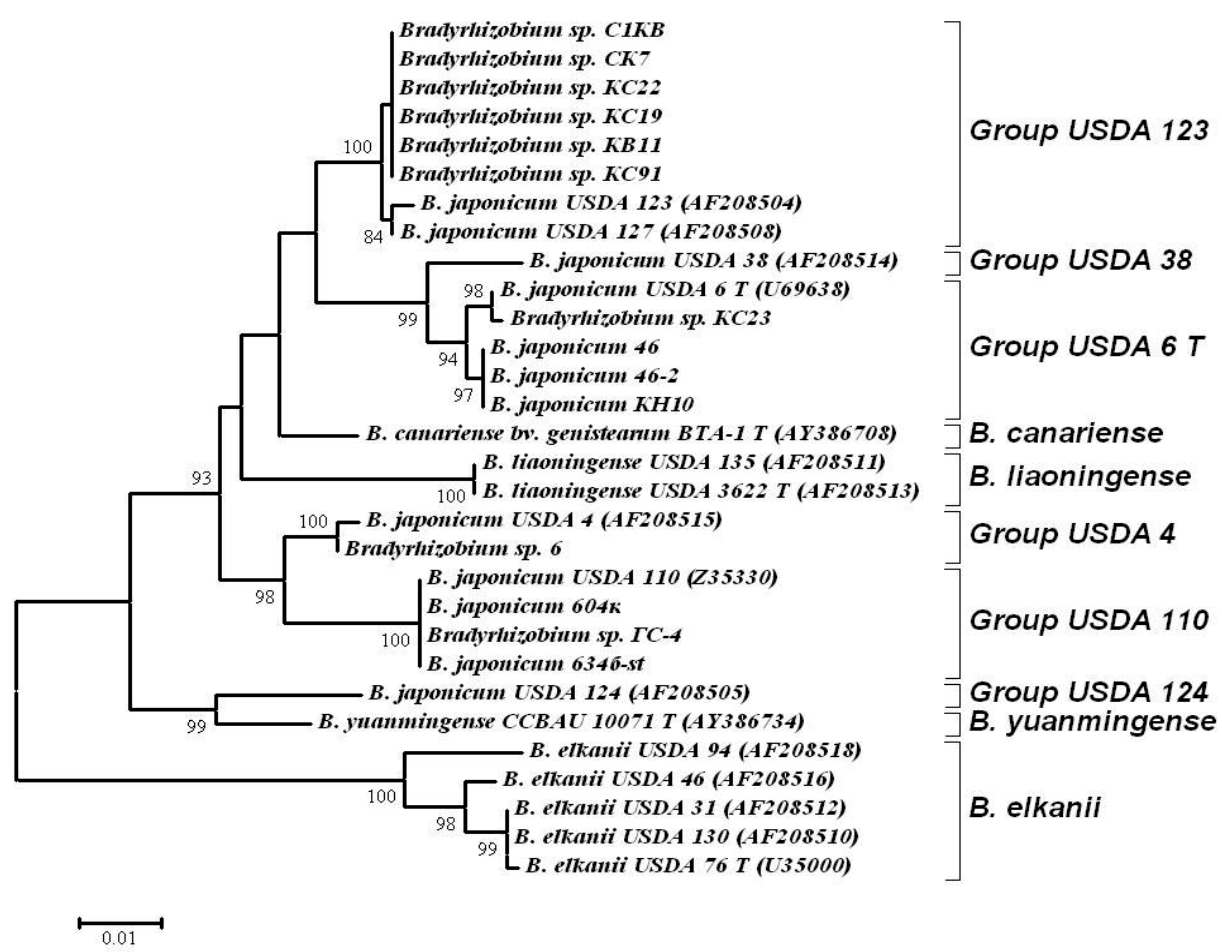

Fig. 1. Phylogenetic tree designed based on the comparative analysis of sequences of intergenic region 16S-23S rDNA of soybean nodule bacteria with the use of the Neighbor-Joining algorithm. The scale corresponds with 1 substitution to 100 founding pair (evolutionary distances). The figures show the statistical reliability of branching order (in \%), which is estimated with the help of "bootstrap" - the analysis of 1000 alternative tree

of strains phylogenetically distant from slow-growing rhizobia. Their ITS sequences were $99.5-99.8 \%$ similar to the sequences of strains B. japonicum USDA 123 and B. japonicum USDA 127 (from GenBank), which belonged to serogroup 123 known in the literature. A special feature of these strains is the greater saprophytic competence, i. e. the ability of nodule bacteria to survive in soil without a host plant [16]. We should note that obtained strains with intensive growth rate also survive better in soil and are dominant in many local populations of soybean rhizobia [5].

Thus, in soils of Ukraine there are both the typical slow-growing soybean nodule bacteria and strains with intensive growth rate. They differ in genotypic as well as phenotypic properties, which may determine the specifics of interaction of strains among themselves and with a host plant.

Production of phytohormones by strains Bradyrhizobium japonicum. In laboratory experiments, we studied the ability of strains belonging to different genetic groups (USDA 6 and USDA 123) to synthesize phytohormonal compounds. We used strains B. japonicum 46 and B. japonicum KB11 both separately and together in a 1:1 ratio. It was found that in cuttings of common bean cultivar 'Lopata' the formation of roots (rhizogenesis) was more intensive at 1:10, 1:50 and 1:100 dilutions of culture liquids of slow-growing $B$. japonicum strain 46 and at 1:200 dilution of intensive-growing $B$. japonicum 
strain KB11. The synergistic action of the strains in their combined usage should be noted. The most active rhizogenic process took place when using the binary composition of strains at dilutions of 1:10, 1:50 and 1:200 (11.9-13.1 units vs. 7.8 units at the control).

The similar tendency was observed when studying the influence of culture liquids of slow- and intensive-growing strains on the weight of roots in common bean cuttings (Fig. 2). Applying each of the strains separately, the maximum root weight gain (73.7-76.8 \% compared to the absolute control) was observed at a 1:200 dilution of culture liquid. When applying together culture liquids of strains with different growth rates in dilutions of 1:10, 1:50 and 1:200, the weight of roots from one cutting of common bean was greater than when using IAA $10^{-5} \mathrm{M}(510-520 \mathrm{mg}$ to $430 \mathrm{mg}$ respectively).

Thus, soybean rhizobia strains with slow and intensive growth rates are able to produce phytohormonal substances that affect rhizogenesis of common bean increasing the number and weight of roots in the cuttings. The growstimulating effect was more evident when using the binary composition of strains B. japonicum $46+B$. japonicum KB11. In our opinion, this could be correlated with production by these strains of biologically active substances differing in their action, the summary effect of which is intensification of the rooting of common bean cuttings.

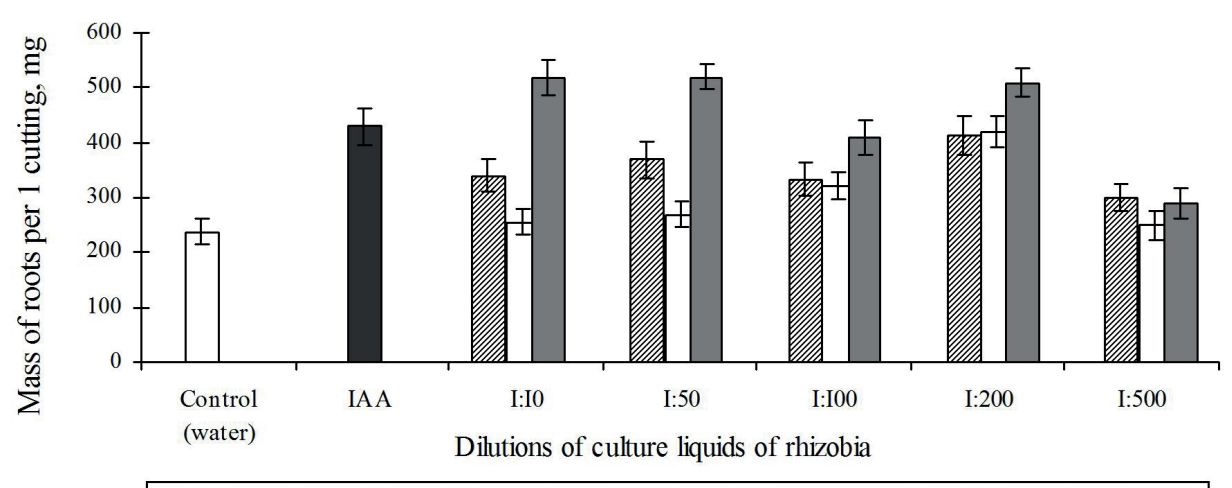

国 B.japonicum $46 \quad \square$ B.japonicum KBII $\square$ B.japonicum 46 + B.japonicum KBII

Fig. 2. Effect of culture liquids of soybean nodule bacteria strains with slow and intensive growth rates on the weight of roots in cuttings of common bean cultivar 'Lopata'

It is known that among all classes of phytohormones the role of signaling molecules which regulate metabolitic reactions, particularly in the formation and active functioning of the legume-rhizobium symbiosis, belongs to auxins, cytokinins, abscisic acid and their correlation [8]. Also, investigation of rhizobia phytohormones spectrum is important for estimating their symbiotic potential.

Determination of the qualitative and quantitative composition of phytohormones by SDTLC-chromatography of high resolution have revealed that slowand intensive-growing strains of soybean nodule bacteria (B. japonicum 46 and B. japonicum KB11) are able to synthesize indole compounds (Table 1). 
Table 1

Production of extracellular phytohormones by Bradyrhizobium japonicum strains with different growth rate

\begin{tabular}{|c|c|c|}
\hline \multirow{2}{*}{ Phytohormones } & \multicolumn{2}{|c|}{$\begin{array}{c}\text { Amount of phytohormones, } \\
\text { mcg/g of absolutely dry biomass }\end{array}$} \\
\cline { 2 - 3 } & B. japonicum $\mathbf{4 6}$ & B. japonicum KB11 \\
\hline Auxins, including: & $\mathbf{4 8 . 4 0}$ & $\mathbf{3 4 . 2 0}$ \\
\hline Indole-3-acetic acid (IAA) & 30.40 & 34.20 \\
\hline Indole-3-butyric acid & 18.00 & - \\
\hline Cytokinins, including: & $\mathbf{3 2 8 . 5 0}$ & $\mathbf{8 3 5 . 3 0}$ \\
\hline Zeatin & 25.30 & 20.60 \\
\hline trans-Zeatin-riboside & 303.20 & 814.70 \\
\hline Abscisic acid & - & - \\
\hline
\end{tabular}

«-»- phytohormones not detected.

When cultivated in the yeast-mannitol medium, both strains synthesized an equal amount of IAA. However, the summary level of auxins synthesis in slow-growing $B$. japonicum strain 46 was higher $(48.40 \mathrm{mcg} / \mathrm{g}$ ADB) than in intensive-growing B. japonicum strain KB11 (34.20 mcg/g ADB). In its supernatant not only IAA but also indole-3-butyric acid $(18.00 \mathrm{mcg} / \mathrm{g}$ ADB) was found, which could be regarded as a spare form of IAA [17]. The studied strains did not synthesize such indole compounds as indole-3-carboxylic acid, indole-3-acetic hydrazide and indole-3-carboxaldehyde.

Among cytokinins synthesized by soybean rhizobia with different growth rates, zeatin and trans-zeatin-riboside were found, the total content of which differed substantially: $B$. japonicum strain 46 synthesized $328.50 \mathrm{mcg} / \mathrm{g}$ ADB of cytokinins and $B$. japonicum strain KB11 - $835.30 \mathrm{mcg} / \mathrm{g}$ ADB. The level of production of zeatin by studied strains was almost the same (25.30 and $20.60 \mathrm{mcg} / \mathrm{g}$ ADB respectively). However, intensive-growing B. japonicum strain KB11 synthesized much more amount of a transport form of cytokinins - trans-zeatin-riboside ( $814.70 \mathrm{mcg} / \mathrm{g} \mathrm{ADB})$-compared to slow-growing B. japonicum strain $46(303.20 \mathrm{mcg} / \mathrm{g}$ ADB $)$. It is very likely that the increased ability of this strain to produce phytohormones with cytokinin nature can affect its interaction with a macro-symbiont. Yet it is known that the higher the ability of rhizospheric bacteria to synthesize ribosylation forms of cytokinins, the higher the level of their specialized adaptation to a host plant [18].

Strains B. japonicum 46 and B. japonicum KB11 did not synthesize abscisic acid, which is a phytohormone that can inhibit the plant growth and development.

Therefore, the studied strains of soybean nodule bacteria differ in the level of synthesis of extracellular phytohormones: slow-growing $B$. japonicum strain 46 produces more amounts of auxins, whereas intensive-growing $B$. japonicum strain KB11 essentially exceeds in the amounts of cytokinins. Revealed differences in the production of phytohormones can play an important part in the colonization of a root and formation of nodules.

Competitiveness and symbiotic effectiveness of soybean nodule bacteria strains. The field research was carried out on leached black soil in the conditions of Polissia of Ukraine. In the control variant on the roots of soybean plants 
solitary nodules were found that indicated the presence of a small population of specific nodule bacteria in the soil. Serological analysis of homogenates of nodules revealed that members of the population belonged to the same serogroup - M8.

Against the background of local population of rhizobia the inoculation of soybean seeds with strains with slow (B. japonicum 46, M8 and 634b) and intensive (B. japonicum KB11) growth rates contributed to an increase in the number of nodules up to 3.4-3.8 times compared to the control (Table. 2). Under the conditions of combined processing of soybean with strains with different growth rates, the process of nodulation was even more active - the number of nodules on the roots of plants was 1.2-2.1 times greater compared to the mono-inoculation. The maximum amount (16.3 unit/plant) and the greatest increase in weight of nodules ( $0.35 \mathrm{~g}$ per plant) were observed when applying the binary composition of strains B. japonicum $46+$ B. japonicum KB11.

Activity of symbiotic nitrogen fixation in the variants with binary compositions of strains was also significantly higher (1.3-1.7 times) comparing to mono-inoculation.

Table 2

\section{Influence of slow and intensive-growing rhizobia strains on symbiotic parameters and productivity of soybean cultivar 'Ustia'} (field experiment, 2013)

\begin{tabular}{|c|c|c|c|c|}
\hline \multirow[b]{2}{*}{$\begin{array}{l}\text { Variants of the } \\
\text { experiments }\end{array}$} & \multicolumn{3}{|c|}{ Beans filling } & \multirow[b]{2}{*}{$\begin{array}{c}\text { Yield, } \\
\text { tons/ } \\
\text { ha }\end{array}$} \\
\hline & $\begin{array}{l}\text { Amount of } \\
\text { nodules, } \\
\text { pieces/ } \\
\text { plant }\end{array}$ & $\begin{array}{l}\text { Weight of } \\
\text { nodules, } \\
\text { gram/ } \\
\text { plant }\end{array}$ & $\begin{array}{c}\text { Nitrogenaze } \\
\text { activity of } \\
\text { nodules, meg } \mathbf{N} \\
\text { per plant } \\
\text { per hour }\end{array}$ & \\
\hline $\begin{array}{l}\text { Without inoculation } \\
\text { (control sample) }\end{array}$ & 2.75 & 0.15 & 4.34 & 2.23 \\
\hline Inoculation with $B$. japonicum 46 & 9.33 & 0.25 & 10.65 & 2.61 \\
\hline Inoculation with $B$. japonicum M8 & 9.50 & 0.25 & 7.44 & 2.53 \\
\hline Inoculation with B. japonicum КВ11 & 10.42 & 0.21 & 8.62 & 2.55 \\
\hline $\begin{array}{l}\text { Inoculation with } B \text {. japonicum } 46+ \\
\text { B. japonicum } \mathrm{KB} 11\end{array}$ & 16.33 & 0.35 & 14.39 & 2.90 \\
\hline $\begin{array}{l}\text { Inoculation with } B \text {. japonicum } \mathrm{M} 8+ \\
\text { B. japonicum KB11 }\end{array}$ & 12.92 & 0.31 & 13.14 & 2.72 \\
\hline $\begin{array}{l}\text { Inoculation with } B \text {. japonicum } 634 \mathrm{~b}+ \\
\text { B. japonicum KB11 }\end{array}$ & 12.00 & 0.23 & 11.54 & 2.64 \\
\hline $\mathrm{LSD}_{05}$ & 2.32 & 0.06 & 1.94 & 0.18 \\
\hline
\end{tabular}

LSD - Least Significant Difference.

Analysis of homogenates of nodules in the reaction of agglutination revealed that, against the background of the small population of specific rhizobia, application of the strain-inoculum significantly affected the process of infecting soybean plants (Table 3 ). Thus, when inoculating soybean with strains $B$. japonicum KB11 and 46, the percent of nodules formed by local nodule bacteria 
of serogroup M8 significantly decreased (3.4-6.8 times respectively), whereas the introduced strains formed the vast majority of nodules (70.8-85.4\%).

Under the conditions of combined inoculation of soybean with nodule bacteria with different growth rates the more even distribution of strains in a "nodule population" was observed. Thus, the part of slow-growing strains B. japonicum $634 \mathrm{~b}$ and 46 in the nodules ranged from $37.0 \%$ to $62.5 \%$. In fewer numbers of nodules B. japonicum strain KB11 was found (22.9-45.8\%). Representatives of the soil population of soybean rhizobia formed only $14.6-30.4 \%$ nodules.

Table 3

Competitiveness of soybean nodule bacteria with slow and intensive growth rate (field experiment, 2013)

\begin{tabular}{|l|c|c|c|c|}
\hline \multirow{2}{*}{\multicolumn{1}{|c|}{$\begin{array}{c}\text { Variants of the } \\
\text { experiments }\end{array}$}} & \multicolumn{4}{c|}{ \% Nodule occupancy by: } \\
\cline { 2 - 5 } & KB11 & $\mathbf{4 6}$ & M8 & 634b \\
\hline $\begin{array}{l}\text { Without inoculation } \\
\text { (control sample) }\end{array}$ & 0 & 0 & 100.0 & 0 \\
\hline Inoculation with B. japonicum 46 & 0 & 85.4 & 14.6 & 0 \\
\hline Inoculation with B. japonicum M8 & 0 & 0 & 100.0 & 0 \\
\hline Inoculation with B. japonicum KB11 & 70.8 & 0 & 29.2 & 0 \\
\hline $\begin{array}{l}\text { Inoculation with B. japonicum 46+ } \\
\text { B. japonicum KB11 }\end{array}$ & 22.9 & 62.5 & 14.6 & 0 \\
\hline $\begin{array}{l}\text { Inoculation with B. japonicum M8+ } \\
\text { B. japonicum KB11 }\end{array}$ & 45.8 & 0 & 54.2 & 0 \\
\hline $\begin{array}{l}\text { Inoculation with B. japonicum 634b }+ \\
\text { B. japonicum KB11 }\end{array}$ & 32.6 & 0 & 30.4 & 37.0 \\
\hline
\end{tabular}

It should be noted that, against the background of a small soil population of rhizobia, the intensive-growing B. japonicum strain KB11 shows high competitiveness and forms a vast majority of nodules $(70.8 \%)$, whereas, when applying together slow-growing strains $B$. japonicum 46, M8 and 634b, its competitiveness is reduced (22.9-45.8\% nodules). This indicates the high intraspecific competition between the strains of nodule bacteria of different serological and genetic groups.

Processing of soybean seeds with studied strains contributed to increase in yield productivity by $13.5-17.0 \%$ comparing to the control (Table 2 ). When applying together the slow- and intensive-growing strains, the yield was 18.4$30.0 \%$ higher. This indicator was maximal (2.90 t/ha) when using the binary composition of strains B. japonicum $46+$ B. japonicum KB11.

Analysis of the results of serological study of nodules and the harvest data indicates that the dominance of active strains with both the slow and intensive growth rates in nodules is not always essential to increase the yield of soybean. In our judgment, the more important is the formation of balanced symbiotic soybean systems with several complementary but serologically and genetically different strains of rhizobia of the same species.

Such symbiotic systems can be formed when using together several strains of nodule bacteria with different growth rates. In addition, each of the strains, including saprophytically existing, occupies its ecological niche and contributes to the formation of active symbiosis.

The maximal positive effect obtained by using together slow- and intensive- 
growing strains $B$. japonicum 46 and $B$. japonicum KB11 can be explained by the synergistic action of these strains, each of them is characterized by a set of valuable features. In functional terms, they complement and reinforce each other's action, allowing to more fully realizing their symbiotic potential. It is possible that this can be connected with achievement of balance in providing plants of this variant with phytohormonal substances that are able to increase the number of potential objects of infection.

It should be noted that some researchers point to existence of the intracultivar variability of legumes by symbiotic characteristics $[19,20]$. We believe that the combined inoculation of soybean seed with two strains complementary to different genotypes, present in a cultivar, can improve the overall effectiveness of symbiosis and, therefore, the soybean yield.

The similar results were obtained in the field experiments with pea and described in the literature [21]. According to the authors, the poly-strain (twothree strains) inoculation of pea provided higher and more stable yields than the mono-strain one. The conclusions have been made about the prospects of poly-strain preparations for growing pea.

The further study of the relationships of soybean with nodule bacteria belonging to different genetic groups is an important and promising area of research from the general scientific as well as practical point of view.

\section{Д.В. Крутило ${ }^{1}$, Н.О. Леонова ${ }^{2}$}

${ }^{1}$ Інститут сільськогосподарської мікробіологї̈ та агропромислового виробництва НААН, вул. Шевченка, 97, Чернігів, 14027, Україна

${ }^{2}$ Інститут мікробіології і вірусології ім. Д.К. Заболотного НАН України, вул. Академіка Заболотного, 154, Київ, 03143, Украӥна

\section{СИМБІОТИЧНИЙ ПОТЕНЦАЛ ШТАМІВ BRADYRHIZOBIUM JAPONICUM 3 РІЗНОЮ ШВИДКІСТЮ РОСТУ}

\section{Резюме}

Mema. Вивчити генетичні властивості бульбочкових бактерій сої з різною швидкістю росту, дослідити здатність ризобій до продукування фітогормональних речовин, а також оцінити їх симбіотичний потенціал за сумісної та моноінокуляції рослин сої. Методи. Сиквенування міжгенного спейсера 16S-23S рДНК штамів ризобій сої здійснювали на генетичному ДНК-аналізаторі АВI 3130xl Genetic Analyzer. Визначення якісного та кількісного складу фітогормонів у культуральних рідинах штамів Bradyrhizobium japonicum визначали методом спектроденситометричної тонкошарової хроматографії. Симбіотичний потенціал штамів оцінювали у польовому досліді в зоні Полісся України. Результати. Встановлено, що штами бульбочкових бактерій сої з різною швидкістю росту за структурою ITS-регіону належать до різних генетичних груп: USDA 6, USDA 110 та USDA 123. Досліджувані ризобії розрізняються за рівнем синтезу позаклітинних фітогормонів: повільнорослий штам B. japonicum 46 продукує більшу кількість ауксинів, тоді як інтенсивнорослий штам $B$. jаропісит КВ11 значно переважає за кількістю цитокінінів. Показано, що важливим фактором підвищення продуктивності сої є формування збалансованих симбіотичних систем рослини-господаря з кількома комплементарними, проте серологічно та генетично відмінними штамами ризобій одного виду. Висновки. Сумісна інокуляції насіння сої 
двома активними штамами $B$. japonicum 46 і B. japonicum КВ11 дозволяє більш повно реалізувати потенціал симбіотичних партнерів та отримати вищий врожай.

Ключові слова: Bradyrhizobium јаропісит, соя, 16S-23S рДНК (ITS-регіон), ауксини, цитокініни, конкурентоспроможність.

\title{
Д.В. Крутило, Н.О. Леонова
}

\author{
${ }^{1}$ Институт сельскохозяйственной микробиологии и агропромышиенного производства \\ НААН, ул. Шевченко, 97, Чернигов, 14027, Украина \\ ${ }^{2}$ Институт микробиологии и вирусологии им. Д.К. Заболотного НАН Украинь,, \\ ул. Академика Заболотного, 154, Киев, 03143, Украина
}

\section{СИМБИОТИЧЕСКИЙ ПОТЕНЦИАЛ ШТАММОВ ВRADYRНIZOBIUM JAPONICUM С РАЗНОЙ СКОРОСТЬЮ РОСТА}

Резюме

Цель. Изучить генетические свойства клубеньковых бактерий сои с разной скоростью роста, исследовать способность ризобий к продуцированию фитогормональных веществ, а также оценить их симбиотический потенциал при совместной и моноинокуляции растений сои. Методы. Секвенирование межгенного спейсера $16 \mathrm{~S}-23 \mathrm{~S}$ рДНК штаммов ризобий сои проводили на генетическом ДНК-анализаторе АВI 3130xl Genetic Analyzer. Определение качественного и количественного состава фитогормонов в культуральных жидкостях штаммов Bradyrhizobium japonicum осуществляли методом спектроденситометрической тонкослойной хроматографии. Симбиотический потенциал штаммов оценивали в полевом опыте в зоне Полесья Украины. Результаты. Установлено, что штаммы клубеньковых бактерий сои с разной скоростью роста по структуре ITS-региона принадлежат к различным генетическим группам: USDA 6, USDA 110 и USDA 123. Исследованные ризобии различаются по уровню синтеза фитогормонов: медленнорастущий штамм B. japonicum 46 продуцирует большее количество ауксинов, тогда как интенсивнорастущий штамм B. japonicum КВ11 значительно преобладает по количеству цитокининов. Показано, что важным фактором повышения продуктивности сои является формирование сбалансированных симбиотических систем растения-хозяина с несколькими комплементарными, однако серологически и генетически отличными штаммами ризобий одного вида. B blводы. Совместная инокуляция семян сои двумя активными штаммами B. japonicum 46 и B. japonicum КВ11 позволяет более полно реализовать потенциал симбиотических партнеров и получить высокий урожай.

Ключевые слова: Bradyrhizobium јаропісит, соя, 16S-23S рДНК (ITS-регион), ауксины, цитокинины, конкурентоспособность.

1. Biological nitrogen fixation, 2 Volume Set / Ed. F.J. de Bruijn. - John Wiley \& Sons. 2015. $-1260 \mathrm{p}$.

2. Kots S.Ya., Morgun V.V., Patyka V.F. et al. Biological nitrogen fixation: legumerhizobial symbiosis. - Vol. 2 . - Kiev.: Logos, 2011. - 523 p. (in Russian).

3. Krutylo D.V., Nadkernychna O.V., Kovalevska T.M., Patyka V.P. Biological diversity of soybean nodule bacteria in soils of Ukraine // Microbiol. Zh. - 2008, - 70, N 6. P. 27-34. (in Ukrainian).

4. Krutylo D.V., Volkova I.V. Serological diversity of soybean nodule bacteria in Ukraine soils // Agroecol. J. - 2012. - N 4. - P. 66-71. (in Ukrainian). 
5. Krutylo D.V., Ushakova M.A., Kolesnik S.I., Ivanyuk S.V., Kobak S.Y. Strain of soybean nodule bacteria having high saprophytic competence as the basis of biopreparations // Feeds and Feed Productions. - 2015. - Issue. 80. - P. 59-65. (in Ukrainian).

6. Krutylo D.V., Zotov V.S. Genotypic analysis of nodule bacteria nodulating soybean in soils of Ukraine // Russian Journal of Genetics: Applied Research. - 2015. - Vol. 5, Issue 2. - P. 102-109.

7. Leonova N.O., Dankevich L.A., Dragovoz I.V., Patyka V.F., Iutynska G.O. Synthesis of extracellular phytohormones-stimulators by nodule bacteria and bacteria phytopathogenic for soybean // Reports of the NASU. - 2013. - N 3. - P. 165-171. (in Ukrainian).

8. Spaepen S., Vanderleyden J., Remans R. Indole-3-acetic acid in microbial and microorganism-plant signaling // FEMS Microbiol. Rev. - 2007. - 31. - P. 425-448.

9. Held M., Hou H., Miri M., Huynh Ch., Ross L., Hossain M.S., Sato S., Tabata S., Perry J., Wang T.L., Szczyglowski K. Lotus japonicus cytokinin receptors work partially redundantly to mediate nodule formation // Plant Cell. - 2014. - 26, N 2. - P. 678-694.

10. Savinskiy S.V., Kofman I.Sh., Kofanov V.I., Stasevskaya I.L. Methodological approaches to the determination of plant hormones using spectrodensitometry thin layer chromatography // Physiol. Biochem. Cult. Plants. - 1987, 19 (2), - P. 210-215. (In Russian).

11. Leonova N.O. Auxins and cytokinines synthesis by Bradyrhizobium japonicum under flavonoids influence // Microbiol. Zh. - 2015. - 77, N 5. - P. 95-103. (in Ukrainian).

12. Methodical recommendations by phytohormones definition. Kyiv: Inst. of Botany of NASU. 1988, 78 p. (in Russian).

13. Normand P., Ponsonnet C., Nesme X. et al. ITS analysis of prokaryotes // Mol. Microbial Ecology Manual. - 1996. - 5, N 3-4. - P. 1-12.

14. Ponsonnet $C$., Nesme $X$. Identification of Agrobacterium strains by PCR-RFLP analysis of pTi and chromosomal regions // Arch. Microbiol. - 1994. - 161. - P. 300-309.

15. Krutylo D.V. The competitiveness of soybean nodule bacteria strains with slow and intensive growth rate // Agricultural Microbiology. - 2011. - Issue 14. - P. 64-76. (in Ukrainian).

16. Godoy L.P., Vasconcelos A.T.R., Chueire L.M.O. et al. Genomic panorama of Bradyrhizobium japonicum CPAC 15, a commercial inoculant strain largely established in Brazilian soils and belonging to the same serogroup as USDA 123 // Soil Biology and Biochemistry. - 2008. - 40, N 11. - P. 2743-2753.

17. Epstein E., Müller J.-L. Indole-3-butyric acid in plants: occurrence, synthesis, metabolism and transport // Physiol. plantarum. - 1993. - 88. - P. 382-389.

18. Metabolism and molecular activities of cytokinins / Eds. J. Guern, C. Peaud-Lenoel. Springer Science \& Business Media. - 2012. - 354 p.

19. Genetics of symbiotic nitrogen fixation with basics of selection / Ed. Tikhonovich I.A. and Provorov N.A. - St. Petersburg: Nauka, 1998. - 194 p. (in Russian).

20. Provorov N.A. Evolution of plant-microbial symbioses: phylogenetic, population, genetic and selection aspects, Extended abstract of doctoral dissertation. - St.-Petersburg, 2009. - 76 p. (in Russian).

21. Chunderova A.I., Seliverstova T.I., Alisova C.M., Orlova I.F. Efficiency of poly-strains inoculation of pea // Tr. VNII s.-h. mikrobiologii. - Leningrad, 1978. - Vol. 47. P. 74-83. (in Russian).

Отримано 01.07.2016 